\title{
TI-RICH AND TI-POOR GARNET FROM THE TAPIRA CARBONATITE COMPLEX, SE BRAZIL: FINGERPRINTING FRACTIONAL CRYSTALLISATION AND LIQUID IMMISCIBILITY
}

\author{
José A. Brod ${ }^{1,2}$, Tereza C. Junqueira-Brod ${ }^{1,2}$, José C. Gaspar ${ }^{1,2}$, Sally A. Gibson ${ }^{3}$ and Robert N. \\ Thompson ${ }^{4}$ \\ ${ }^{1}$ Universidade de Brasília, Brazil, ${ }^{2} \mathrm{CNPq}$, Brazil, ${ }^{3}$ Cambridge University, $U K,{ }^{4}$ University of Durham, UK
}

\section{INTRODUCTION}

The Tapira complex is located in western Minas Gerais State (Figure 1), $30 \mathrm{~km}$ southeast of the city of Araxá. It is the southernmost $\left(19^{\circ} 53^{\prime} \mathrm{S} ; 46^{\circ} 50^{\prime} \mathrm{W}\right)$ in a series of Late-Cretaceous, carbonatite-bearing alkaline plutonic complexes which, together with kamafugites, lamproites and kimberlites, form the Late-Cretaceous Alto Paranaíba Igneous Province (APIP, Gibson et al. 1995). The complex intrudes the Late-Proterozoic Brasília mobile belt, near the southwest margin of the São Francisco Craton. The country rocks were deformed into a dome structure, as well as mildly fenitised and thermally affected by the intrusion.

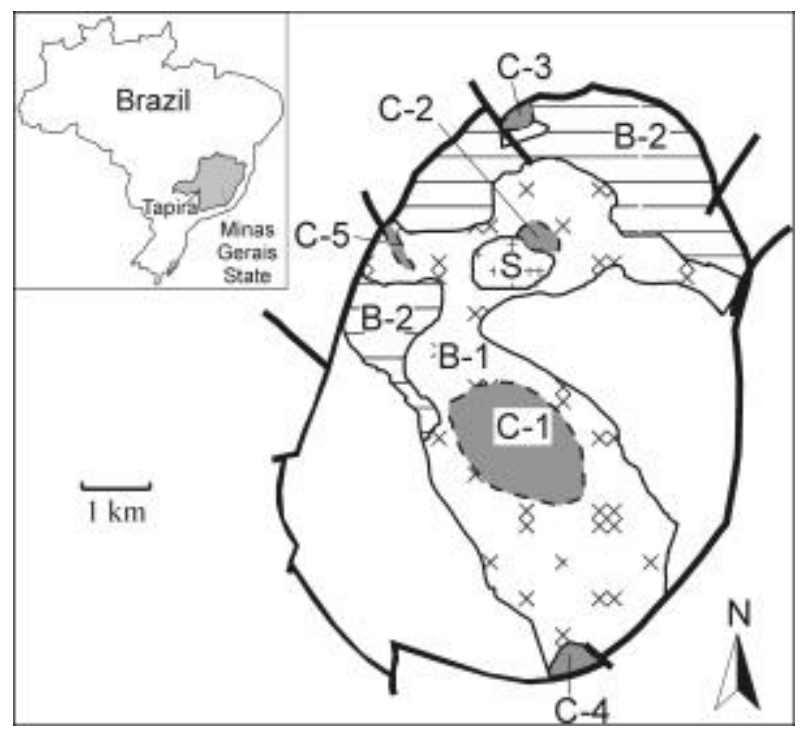

Figure 1: Location and geological sketch of the Tapira Complex (Brod, 1999)

\section{GEOLOGY OF THE TAPIRA COMPLEX}

The complex is roughly elliptical, $35 \mathrm{~km}^{2}$ in area, consisting of bebedourite (alkali clinopyroxenite), with subordinate carbonatite and syenite. Melilitolite and serpentinised dunite are rare. The coarse-grainded rocks are cut by ultramafic dykes of kamafugite affinity.
Economic concentrations of phosphate, $\mathrm{Ti}, \mathrm{Nb}, \mathrm{REE}$ and vermiculite occur in the thick weathering cover.

\section{SILICATE PLUTONIC SERIES (SPS)}

The coarse-grained silicate rocks were collectively named Silicate Plutonic Series (SPS). This is further subdivided (Figure 1) into ultramafic rocks (Units B1 and B2) and syenites (Unit S). Drill core relationships and the mineral chemistry of phlogopite (Brod et al. 2001), spinel (Brod et al. 2003), olivine, clinopyroxene, and perovskite indicate a general magma evolution path in the sense B1 $\Rightarrow \mathrm{B} 2 \Rightarrow \mathrm{S}$ for the SPS (Brod 1999).

\section{Ultramafic plutonic rocks}

Fine- to coarse-grained bebedourites are by far the most abundant ultramafic rock in B1 and B2 units. They represent cumulates from a mafic alkaline magma and consist mainly of diopsidic pyroxene, with variable amounts of phlogopite, perovskite, apatite, magnetite, Ti-garnet and rare sphene. As in other APIP carbonatite complexes, crystal accumulation produced olivine-, perovskite-, magnetite- or apatite-rich facies in addition to typical bebedourite. Whilst such variations are primarily the result of magmatic crystal sorting, some apatite- or perovskite-magnetite-rich rocks may occur as discordant bodies, suggesting mobilisation of a crystal-mush. Rare melilitolites (uncompahgrites) occur near the northeast border of the complex. Syenites, carbonatites, and ultramafic dykes intrude B1 and B2.

\section{Syenites}

These rocks occur either as angular fragments in carbonatite-syenite breccias or as independent intrusions. They are essentially composed of K-feldspar plus phlogopite and/or aegirinic pyroxene, with accessory zircon and sphene. Most coarse-gained syenites represent cumulates of orthoclase crystals. Petrographic and chemical evidence indicate an ultrapotassic affinity (Brod 1999), consistent with that observed for other rock-types in Tapira and in the APIP 


\section{CARBONATITES}

The carbonatites were sub-divided into units $\mathrm{C} 1$ to $\mathrm{C} 5$ (Brod 1999), according to their location and petrographic or compositional features (Figure 1). They range from massive plugs through dykes to small veinlets and intrude the SPS, often converting bebedourites and other ultramafic rocks into phlogopitites. Carbonatite intrusion is commonly associated with brecciation, ranging in style from magmatic stoping to more explosive, diatreme-like facies.

Three compositional types of carbonatite are recognised: (a) sovites (in $\mathrm{C} 1, \mathrm{C} 3$ and $\mathrm{C} 4$ units, Figure 1), (b) dolomite sovites (in $\mathrm{C} 1$ and $\mathrm{C} 2$ Units) and (c) beforsites (C5). Tapira carbonatites were produced by an intricate combination of liquid immiscibility and fractional crystallisation, which is clearly recorded in the mineral chemistry and whole-rock geochemical signatures of both the carbonatites and their silicate counterparts (Brod 1999, Brod et al. 2001, 2003).

\section{ULTRAMAFIC DYKES}

All Tapira plutonic rocks are crosscut by fine-grained ultramafic dykes, usually a few centimetres to tens of centimetres thick, rarely exceeding one metre. On the basis of chemical and mineralogical criteria they can be divided into phlogopite-picrite and bebedouritic dykes. Phlogopite-picrites are the most primitive Tapira rocks, consisting of olivine phenocrysts set in a carbonate- and phlogopite-rich groundmass. In most cases, Flowdifferentiation concentrates phenocrysts in the centre of the dykes. Bebedouritic dykes are slightly more evolved, with rare phlogopite, clinopyroxene and/or apatite phenocrysts set in a groundmass composed of the same phases plus carbonate and magnetite. The parental character and the kamafugitic affinity of the ultramafic dykes were established by Brod (1999) and Brod et al. (2000), thus providing a strong link between the carbonatite-bearing plutonic complexes and the voluminous kamafugitic volcanism in the APIP.

\section{TITANIUM-RICH AND TITANIUM-POOR GARNETS}

Yellow to dark-brown titanian garnets are present in several Tapira rock-types. They may occur as two distinct textural varieties: a) the earliest garnet to appear in the crystallisation history of the complex is an intercumulus phase in the ultramafic coarse-grained rocks; b) garnet of the second variety is a cumulus phase, formed by direct precipitation from the magma, and occurs only in relatively evolved rocks. The two varieties were not found together in the same sample.

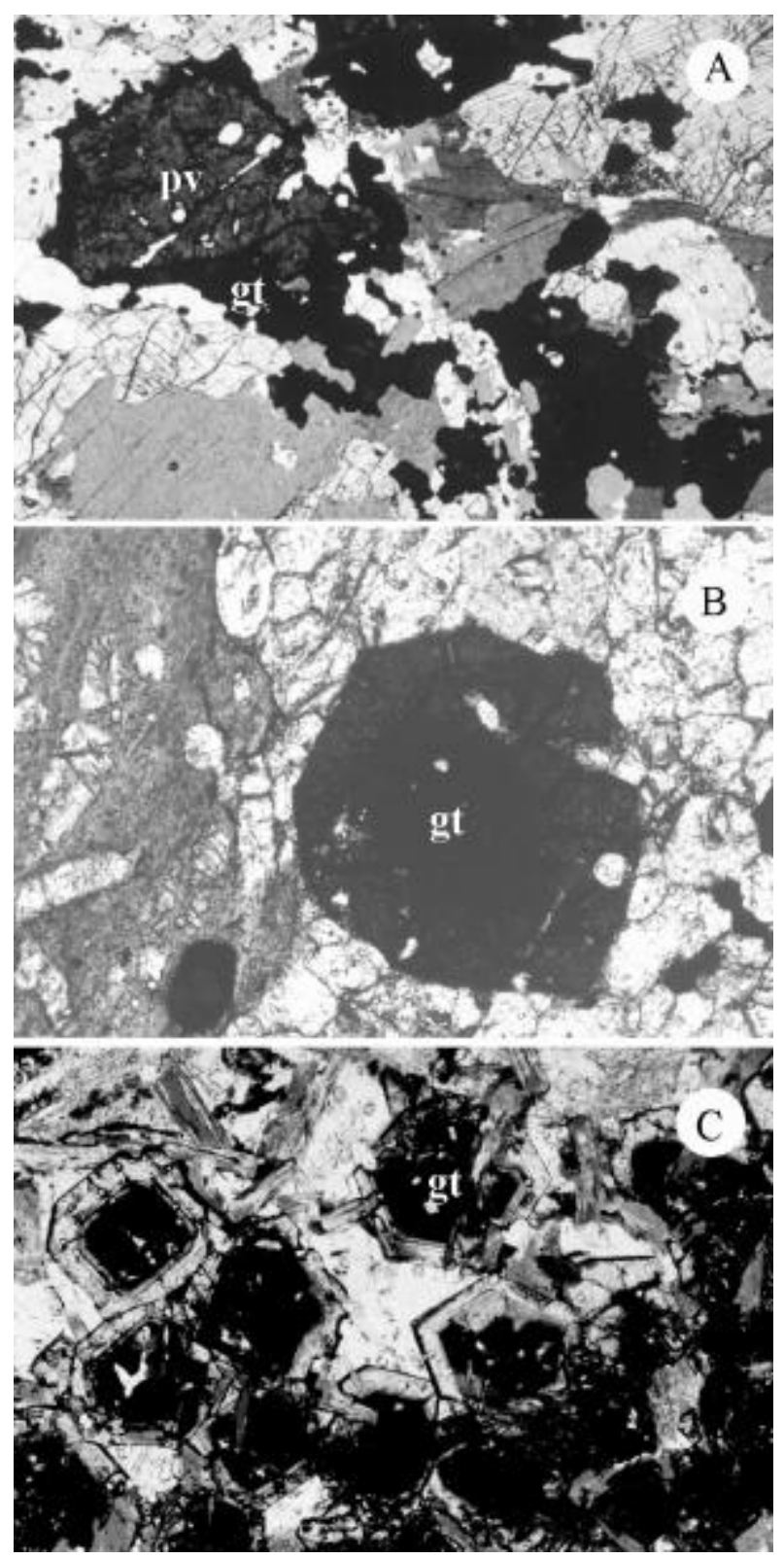

Figure 2: a) intercumulus garnet overgrowth on perovskite crystal from B1 bebedourite; b) primary euhedral garnet in more evolved B2 wehrlite; c) several euhedral, sharply zoned primary garnet crystals in a carbonate-rich groundmass

The intercumulus garnet occurs in wehrlites and bedourites from both the $\mathrm{B} 1$ and the $\mathrm{B} 2$ units, and is the sole garnet variety recorded from B1. The crystals are usually anhedral, varying in colour from very dark brown to nearly opaque (black), optical zoning is either lacking or patchy. This type of garnet is invariably found as a coating on cumulus perovskite (Figure 2a). 
In some cases the garnet appears to be replacing the original perovskite, whereas in others it is clearly overgrown on euhedral crystals. Because other coexisting minerals do not show signs of alteration, it is unlikely that the substitution of garnet for perovskite is a product of metasomatic processes. Instead, textural relationships suggest that the garnet originated by a late-stage $\mathrm{SiO}_{2}$ increase in the intercumulus liquid. This can be readily explained by fractionation of large amounts of non-silicates, such as perovskite, apatite and magnetite, which are common cumulus phases in the host rock.

Garnets of the second variety are a product of direct magmatic crystallisation. They appear for the first time in some wehrlites and bebedourites of the B2 unit, forming discrete crystals which are the main titaniumbearing phase in the rock. Individuals are often euhedral to subhedral and may show concentric optical zoning (Figure 2b). In even more evolved fine-grained dykes, primary garnet coexists with a carbonate-rich groundmass (Figure 2c). Here, all garnet crystals show an abrupt variation in optical properties and chemical composition, changing rapidly from a dark brown (Tirich) core to a light yellow (Ti-poor) rim. It should be noted that, in contrast with the perfectly euhedral shape of the rim, some cores show embayments that indicate partial dissolution into the carbonate-rich liquid. Rocks containing primary garnet typically lack perovskite.

\section{CHEMICAL COMPOSITION}

Tapira garnets are Ca-rich $(30.3$ - 33.7 wt. \% CaO), Alpoor (< 2.4 wt. $\left.\% \mathrm{Al}_{2} \mathrm{O}_{3}\right)$ and $\mathrm{Cr}$-poor $(<0.17$ wt. $\%$ $\mathrm{Cr}_{2} \mathrm{O}_{3}$ ), and contain variable amounts of $\mathrm{TiO}_{2}$ (up to 19.2 wt. \%), thus belonging to the andradite-melaniteschorlomite series.

Deer et al. (1992) classify Ti-rich andradites into melanite and schorlomite, depending on whether $\mathrm{Fe}^{3+}$ or Ti predominates in the octahedral site, placing the limit at approximately $15 \mathrm{wt} . \% \mathrm{TiO}_{2}$. Henmi et al. (1995) proposed the existence of a new titanian garnet end-member, morimotoite $\left(\mathrm{Ca}_{3} \mathrm{Ti}^{4+} \mathrm{Fe}^{2+} \mathrm{Si}_{3} \mathrm{O}_{12}\right)$, derived from andradite by the substitution $\mathrm{Ti}^{4+}+\mathrm{Fe}^{2+} \Leftrightarrow 2 \mathrm{Fe}^{3+}$. However, Fehr and Amthauer (1996) and Rass (1997) argued that this is inconsistent with Mossbauer and XPS evidence.

The valency state and preferential cation distribution of $\mathrm{Ti}$ and $\mathrm{Fe}$ in Ti-rich garnets remain a controversial subject (e.g. Malitesta et al. 1995; Rass 1997). Several site-assignment alternatives have been suggested, invoking combinations of some or all the cations $\mathrm{Fe}^{2+}$,
$\mathrm{Fe}^{3+}, \mathrm{Ti}^{4+}$ and $\mathrm{Ti}^{3+}$, and involving the octahedral, tetrahedral and dodecahedral sites. To avoid controversy, the weight percentage of $\mathrm{TiO}_{2}$ (Deer et al. 1992) is adopted here as the preferred classification criterion. In Figure 3 most analyses fall below 15 wt. \% $\mathrm{TiO}_{2}$ and are classified as melanite. A lesser number of schorlomite, and rare andradite individuals also occur.

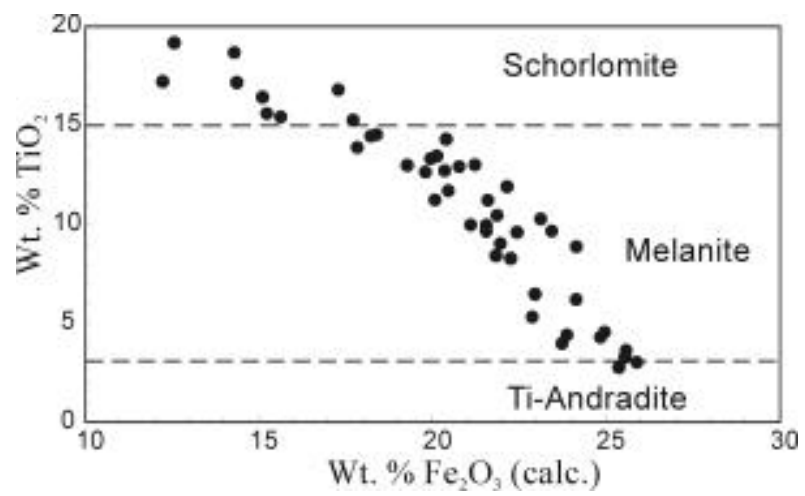

Figure 3: Classification of Tapira garnets based on the $\mathrm{TiO}_{2}$ (wt. \%) content. $\mathrm{Fe}_{2} \mathrm{O}_{3}$ was calculated from the structural formula according to the method of Droop (1987) and updated in the original analysis.

Several minor and trace elements occur in measurable amounts in Tapira garnets. $\mathrm{Na}_{2} \mathrm{O}$ rarely exceeds 0.6 wt. $\%$, whilst $\mathrm{P}_{2} \mathrm{O}_{5}$ may reach up to 0.83 wt. \%. $\mathrm{NiO}$ and $\mathrm{Cr}_{2} \mathrm{O}_{3}$ are low (up to 0.10 and 0.16 wt. \% respectively). $\mathrm{ZrO}_{2}$ may be as high as 2.63 wt. $\%$ and $\mathrm{Nb}_{2} \mathrm{O}_{5}$ may reach 0.3 wt. \%. The sum of $\mathrm{La}, \mathrm{Ce}, \mathrm{Nd}$ and $\mathrm{Gd}$ oxides reaches up to $0.22 \mathrm{wt} . \%$.

\section{ZONING}

The chemical zoning of melanites and schorlomites is correlated with the optical and physical properties of the mineral (e.g. Howie and Woolley 1968; Gomes 1969; Dingwell and Brearley 1985). In particular, the Ti content seems to have a strong effect on the colour, with higher Ti corresponding to darker shades.

A number of points along core-rim traverses were analysed in the strongly zoned garnets of dykes (Figure 2c). The cores are consistently enriched in $\mathrm{Ti}, \mathrm{Mg}$ and $\mathrm{Fe}^{2+}$, while the rims are enriched in $\mathrm{Si}, \mathrm{Fe}^{3+}$, and $\mathrm{Ca}$ (Figure 4). This corresponds to a colour change from dark, deep brown cores to light-yellow rims. Apparently unzoned individual crystals show a similar correlation between colour and chemical composition. In zoned grains, $\mathrm{Nb}, \mathrm{Zr}, \mathrm{P}$, and possibly the REE, are enriched in the dark-coloured cores. 


\section{DISCUSSION AND CONCLUSIONS}

Ti-rich garnets are typical of alkaline rocks (e.g. Keep and Russell 1992; Dingwell and Brearley 1985; Huggins et al. 1977), especially those with a high degree of silica undersaturation. According to Mitchell (1996) schorlomite and Ti-rich andradite are common products of sub-solidus reactions in melilitolite complexes. Platt and Mitchell (1979) considered Zrrich titanian garnets as intimately associated with (and indicative of) magmatism of carbonatitic affinity.

In Tapira, Ti-rich garnets occur as a late-stage product of fractional crystallisation (intercumulus garnet within the ultramafic cumulates) and as euhedral individual crystals, precipitated directly from more evolved magmas of the B2 unit. Their textural and chemical features provide useful evidence for the recognition of crystal fractionation and liquid immiscibility processes.

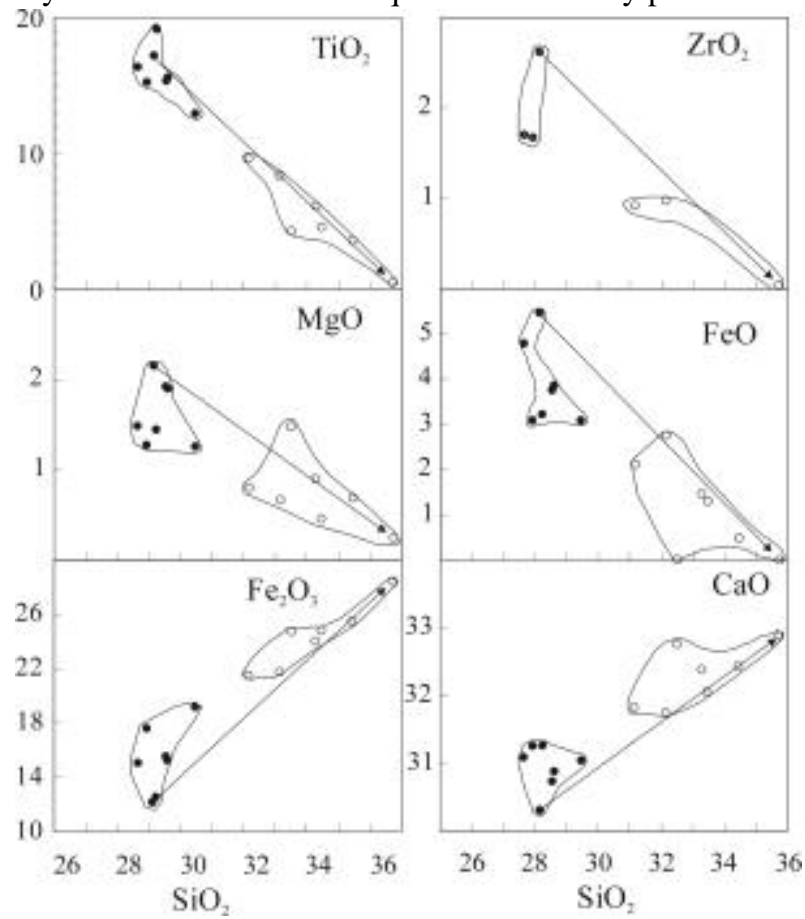

Figure 4: Chemical variation of selected oxides (wt. \%) in sharply zoned garnets from Tapira (Figure 2c). Solid circles = cores, open circles = rims. Arrows indicate the largest core-torim variation found in a single crystal.

\section{FRACTIONAL CRYSTALLISATION}

The melanite coatings on perovskite (Figure 2a) from the $\mathrm{B} 1$ and some of $\mathrm{B} 2$ rocks are best explained by an increase in silica activity in the residual intercumulus liquid. Brod (1999) found that the compositions of clinopyroxene, perovskite and phlogopite in rocks from the SPS varied systematically, in a way that fitted a fractional crystallisation model with the ultramafic rocks as crystal cumulates. In contrast, the intercumulus garnet does not show a systematic composition trend, which is consistent with its late-stage origin. The presence of Ti-garnet, rather than perovskite, as the main Ti mineral crystallising in some B2 wehrlites and bebedourites suggests a lesser degree of silica undersaturation in that magma, relatively to B1. This is in good keeping with the more evolved character of key B2 mineral phases

\section{LIQUID IMMISCIBILITY}

The zoning pattern of some evolved magmatic garnets indicates a relatively late-stage episode of $\mathrm{Ti}$ and $\mathrm{Zr}$ depletion. It could be argued that this results from the fractionation of specific $\mathrm{Ti}$ and $\mathrm{Zr}$ minerals. However, a smoother change in magma composition (and in the composition of the crystallising garnet) would be expected in that case. Instead, the sharp contact and the amplitude of chemical variation (from over $17 \mathrm{wt} . \%$ to 0.5 wt. $\% \mathrm{TiO}_{2}$ and from 2.6 wt. $\%$ to 0.02 wt. $\% \mathrm{ZrO}_{2}$ ) between adjacent zones of garnets such as those in Figure 2c require the intervention of a more dramatic event.

Chemical, mineralogical and petrographic evidence for the involvement of silicate-carbonatite liquid immiscibility in the petrogenesis of the Tapira complex was presented by Brod (1999). It is also well established from experimental studies that elements such as $\mathrm{Ti}$ and $\mathrm{Zr}$ show a strong preference for the silicate immiscible liquid (e.g. Kjarsgaard and Hamilton 1989; Hamilton and Kjarsgaard 1993; Lee and Wyllie 1998; Veksler et al. 1998) becoming, consequently, depleted in the carbonatite counterpart. We conclude that the cores of garnets in Figure 2c started crystallising from a carbonate-rich silicate magma (analogue to the bebedouritic dykes) while their rims formed in a carbonatitic environment, after liquid immiscibility. This agrees with the carbonatitic character of the groundmass depicted in Figure 2c.

\section{ACKNOWLEDGEMENTS}

The authors thank CNPq-Brazilian Council for Research and Development for research grants to JAB and JCG, and a Ph.D. grant to TCJB. The Universities of Brasilia, Durham and Cambridge for providing analytical facilities. Dr. Stephen Reed, at Cambridge University, for the help with microprobe analyses. 


\section{REFERENCES}

Brod, J.A., 1999. Petrology and geochemistry of the Tapira alkaline complex, Minas Gerais State, Brazil. Ph.D. Thesis, Univ. Durham, UK.

Brod J.A., Gibson, S.A., Thompson, R.N., Junqueira-Brod, T.C., Seer, H.J., Moraes, L.C., Boaventura, G.R., 2000. The kamafugite-carbonatite association in the Alto Paranaíba Igneous Province, southeastern Brazil. Revista Brasileira de Geociências. 30:404-408

Brod, J.A., Gaspar, J.C., Araújo, D.P., Gibson, S.A., Thompson, R.N., Junqueira-Brod, T.C., 2001. Phlogopite and tetra-ferriphlogopite from Brazilian carbonatite complexes: petrogenetic constraints and implication for mineral-chemistry systematics. J. Asian Earth Sci., 19: 265-296

Brod, J.A.. Gaspar, J.C., Diniz-Pinto, H.S., Junqueira-Brod, T.C., 2003. Spinel chemistry as an indicator of crystal fractionation and liquid immiscibility in the Tapira alkaline-carbonatite complex, Minas Gerais, Brazil Proc. 8th Int. Conf. Kimberlites, Vancouver, Canada (this volume)

Deer, W.A., Howie, R.A., Zussman, J., 1992. An introduction to rock forming minerals. Longman, Essex.

Dingwell, D.B., Brearley, M., 1985. Mineral chemistry of igneous melanite garnets from analcite-bearing volcanic rocks, Alberta, Canada. Contrib. Mineral. Petrol., 90: 29-35.

Droop, G.T.R., 1987. A general equation for estimating $\mathrm{Fe}^{3+}$ concentrations in ferromagnesian silicates and oxides from microprobe analyses, using stoichiometric criteria. Mineral. Mag., 51: 431-435.

Fehr, K.T., Amthauer, G., 1996. Comment on "Morimotoite, $\mathrm{Ca}_{3} \mathrm{TiFe}^{2+} \mathrm{Si}_{3} \mathrm{O}_{12}$, a new titanian garnet from Fuka, Okayama Prefecture, Japan" by Henmi et al. (1995). Mineral. Mag., 60: 842-845.

Gibson, S.A., Thompson, R.N., Leonardos, O.H., Dickin A.P., Mitchell J.G., 1995. The Late Cretaceous impact of the Trindade mantle plume - evidence from largevolume, mafic, potassic magmatism in SE Brazil. J. Petrol., 36:189-229.

Gomes, C.B., 1969. Electron microprobe analysis of zoned melanites. Am. Mineral., 54:1654-1661.

Hamilton, D.L., Kjarsgaard, B.A., 1993. The immiscibility of silicate and carbonate liquids. South Afr. J. Geol., 96:139-142.
Henmi, C., Kusachi, L, Henmi, K., 1995. Morimotoite, $\mathrm{Ca}_{3} \mathrm{TiFe}^{2+} \mathrm{Si}_{3} 0_{12}$, a new titanian garnet from Fuka, Okayama Prefecture, Japan. Mineral. Mag., 59:115120.

Howie, R.A, Woolley, A.R., 1968. The role of titanium and the effect of $\mathrm{TiO}_{2}$ on the cell-size, refractive index, and specific gravity in the andradite-melaniteschorlomite series. Mineral. Mag., 36: 775-790.

Huggins, F.E., Virgo, D., Huckenholz, H.G., 1977. Titaniumcontaining silicate garnets. I. The distribution of Al, $\mathrm{Fe}^{2+}$, and $\mathrm{Ti}^{4+}$ between octahedral and tetrahedral sites. Am. Mineral. 62:475-490.

Keep, M., Russell, J.K., 1992. Mesozoic alkaline rocks of the Averill plutonic complex. Can. J. Earth Sci., 29:25082520 .

Kjarsgaard, B.A., Hamilton, D.L., 1989. The genesis of carbonatites by immiscibility. In Bell, K. (Ed.), Carbonatites: genesis and evolution. Unwin Hyman, pp. 388-404.

Lee, W.J., Wyllie, P.J., 1998. Petrogenesis of carbonatite magmas from mantle to crust, constrained by the system $\mathrm{CaO}-\left(\mathrm{MgO}+\mathrm{Fe} 0^{*}\right)-\left(\mathrm{Na}_{2} \mathrm{O}+\mathrm{K}_{2} \mathrm{O}\right)-\left(\mathrm{SiO}_{2}+\right.$ $\left.\mathrm{Al}_{2} \mathrm{O}_{3}+\mathrm{TiO}_{2}\right)-\mathrm{CO}_{2}$. J. Petrol., 39:495-517.

Malitesta, C., Losito, L., Scordari, F., Schingaro, E., 1995. XPS investigation of titanium in Melanites from Monte Vulture (Italy). Eur. J. Mineral., 7:847-858.

Mitchell, RH., 1996. The melilitite clan. In: Mitchell R.H. (Ed.), Undersaturated alkaline rocks: mineralogy, petrogenesis, and economic potential. Mineral. Assoc. Can. Short Course, 24:123-151.

Platt, R.G., Mitchell, R.H., 1979. The Marathon dikes. I. Zirconium-rich titanian garnets and manganoan magnesian ulvospinel-magnetite spinels. Am. Mineral., 64:546-550.

Rass, L.T., 1997. Morimotoite, a new titanian garnet? discussion. Mineral. Mag., 61:728-730.

Veksler, L.V., Petibon, C., Jenner, G.A., Dorfinan, A.M., Dingwell, D.B., 1998. Trace element partitioning in immiscible silicate-carbonate liquid systems: An initial experimental study using a centrifuge autoclave. J. Petrol., 39:2095-2104.

Contact: J.A. Brod, Universidade de Brasília, Instituto de Geociências. Brasília, Brazil. 70.910-900. E-mail: brod@unb.br 